واكنش ازدياد حساسيت به بى حسى موضعى در دندانيزشكى: تزارش مورد و مرورى بر مقالات

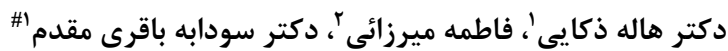

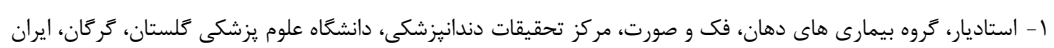

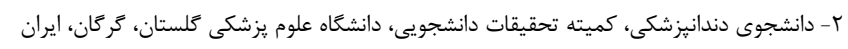

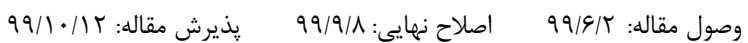

\title{
Hypersensitivity Reaction to Local Anesthetic in Dentistry: A Case Report
}

\author{
Haleh Zokaee', Fatemeh Mirzaei², Sudabe Baghery Moghadam ${ }^{1 \#}$ \\ 1- Assistant Professor, Oral Medicine Dept, Dental Research Center, Golestan University of Medical Sciences, Gorgan, Iran \\ 2- Dentistry Student, Student Research Committee, Golestan University of Medical Sciences, Gorgan, Iran
}

\section{Abstract}

Received: Aug 2020

; Accepted: Feb 2021

Background and Aim: Local anesthesia plays an important role in dentistry. Although hypersensitivity reactions to local anesthetic drugs are rare,but they are more common in dental cartridge components. This study reports a rare case of hypersensitivity to components of local anesthesia cartridge.

Case Report: A 61-year-old female patient referred to The Medical Council to complain the dentist about pigmentation appeared around the eyes and lips. The patient had no history of systemic disease or food and medication allergy, and a year before complaint, had referred to dentist for anterior and premolar teeth extraction. About an hour later, black macules and patches with ill-defined borders appeared in peri-orbit and peri-oral areas. By further examination, hypersensitivity reaction to the local anesthetic cartridge was reported as the most likely diagnosis.

Conclusion: This case states the importance of differentiating the lesion from other causes of pigmentation. It is also recommended to pay attention to the type of local anesthesia cartridge used and its component.

Key words: pigmentation, dentistry, local anesthetics, case report

*Corresponding Author: dr.baqerymoqadam@gmail.com

J Res Dent Sci. 2021;18 (1): 85-90. 
خلاصه:

سابقه و هدف: بى حسى موضعى نقش مهمى در دندانيزشكى ايفا مى كند. اكرجه واكنش ازدياد حساسيت به داروهاى بى حسى

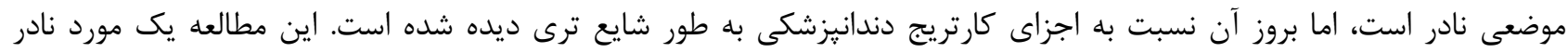

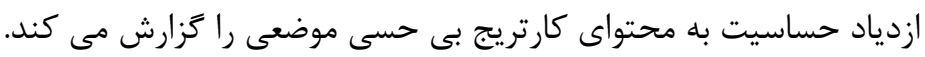

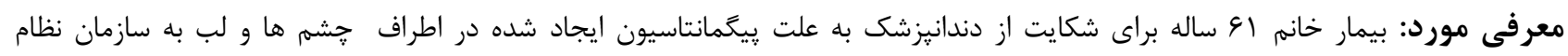

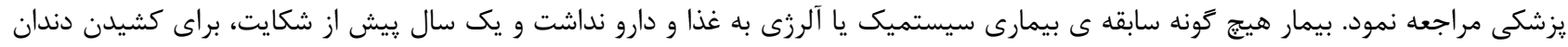

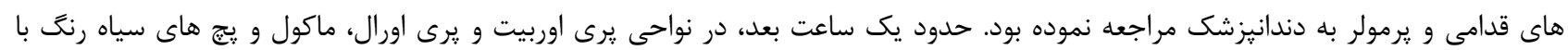

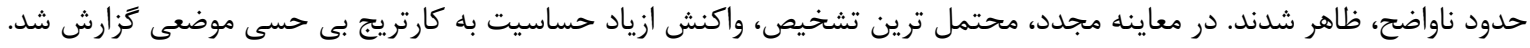

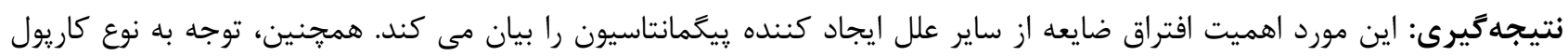

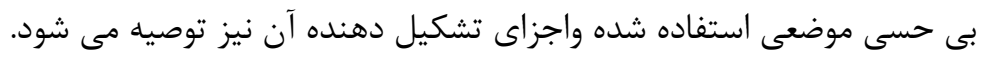

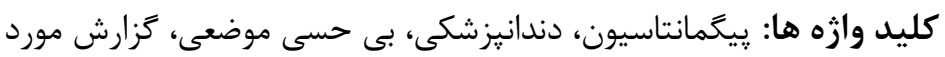

كاريول هاى بى حسى موضعى على رغم كاربرد هـاى فـراوان، مقدمه

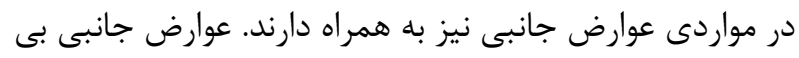
حسى موضعى ممكن است به سه حالت توكسيك، سايكوزنيك،

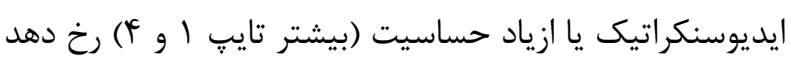
("). بيشتر عوارض جانبى بى حسى هاى موضعى ناشى از علائم

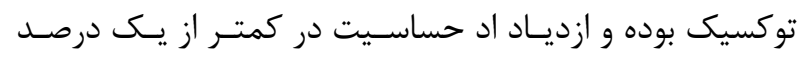
موارد كزارش شده است. بنزوات و متيل يارابن و يروييل يارابن

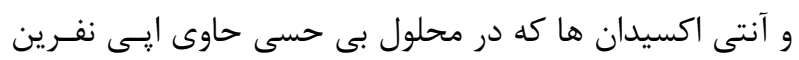

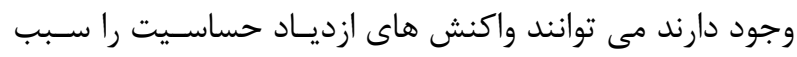

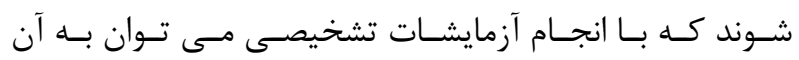

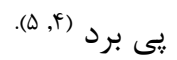

para-amino benzoic ) PABA به علت توليد متابوليت

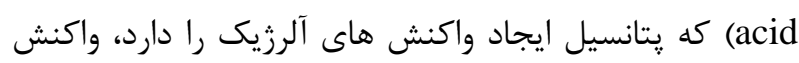

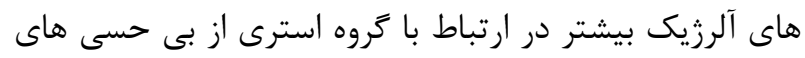

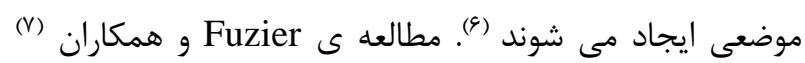

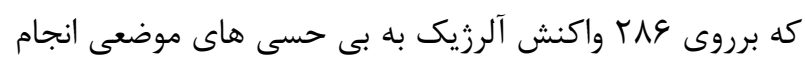

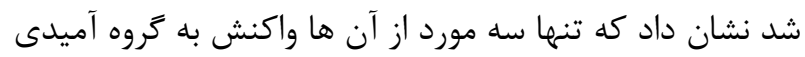
بوده است. با اين حال با توجه به استفاده بيشتر از بى حسى

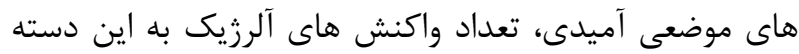
رو به افزايش است موائ اميدى، بى حسى هاى موضعى در دندانيزشكى كاربرد كسترده اي

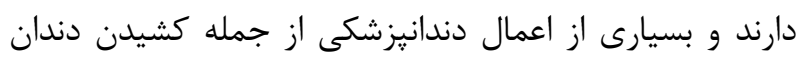

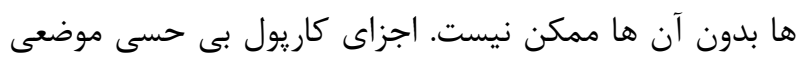
شامل داروى بى حسى موضعى، تنگ كننده ى عروقى، سديم بى سولفات، سديم كلرايد، آب استريل و در مواردى متيل

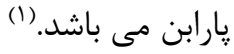
داروهاى بى حسى موضعى به دو دسته داسته ى آميدى

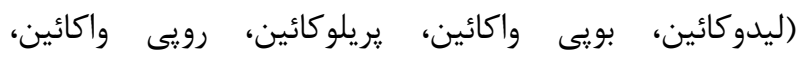
آرتيكائين، ميى واكائين) و استرى (بنزوكائين، كوكائين، يروكائين، تتراكائين) تقسيم مى شوند و به عنوان مسدون

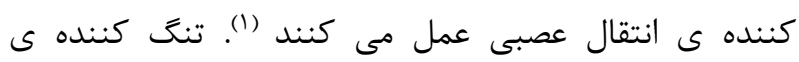
عروقى جذب داروهاى بى حسى موضعى و سميت آن را در اند خون كاهش داده و مدت زمان بى حسى را افزايش مى دهد.

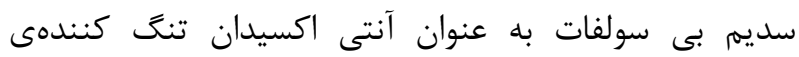
عروقى عمل مى كند و متيل پارابن يك باكتريواستاتيك است كه باعث افزايش نيمه عمر كاريول مى گردد. متيل پيارابن در

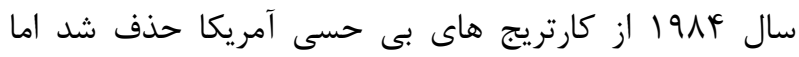
هنوز در برخى كارتريج هاى ساخته شده درخارج آمريكا كاربرد 
تشخيصهايى همجون هماتوم، اكيموز و ليكن پِلان براى بيمار كذاشته شد و داروهاى هيدروكسى كلروكين و داروهاى ديكر

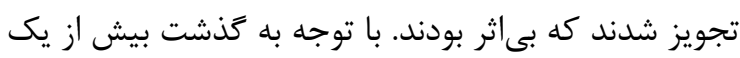
سال از ايجاد ضايعات، امكان انجام بيويسى از محل و تستهاى لابراتوارى سرمى و تست يريك يوستى (Skin Prick Test

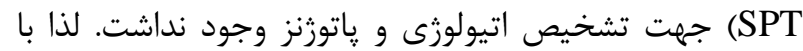
اكتفا به شرحال بيمار و يافتههاى بالينى در روز معاينه، تئه

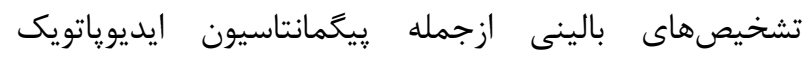

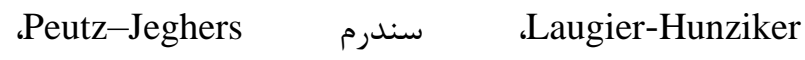
يِيخمانتاسيون senile و واكنش ازدياد حساسيت به محتواى كارتريج بى حسى موضعى براى بيمار مطرح شد. با توجه به محل دركيرى و عدم وجود پِيخمانتاسيون در ساير نقاط بدن، اين ضايعه از پيخمانتاسيون ايديوياتويك Laugier-Hunziker از سندرم Peutz-Jeghers، عدم همراهى آن با اختلال سيستميك ديكر بود. همجنين، بروز ضايعات بلهصورت حاد،

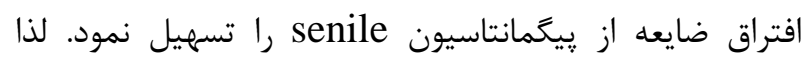
محتملترين تشخيص، واكنش ازدياد حساسيت به محتواى كارتريج بى حسى موضعى كزارش شد و عدم قصور دندانيزشك إنى تاييد شد. با توجه به اينكه بيمار شرايط يزشكى خاصى نداشت، احتمال داده شد كه از كاريول ليدوكايين آدرصد جهت بى حسى موضعى استفاده شده باشد؛ اما از آنجايى كه بيمار جهت شكايت مراجعه نموده بود، مشخصات يزشك معالج مشخص نبود و دسترسى مجدد به بيمار مى توانست حساسيت

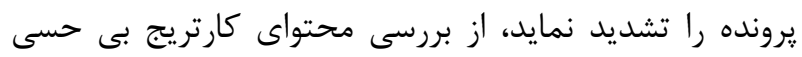

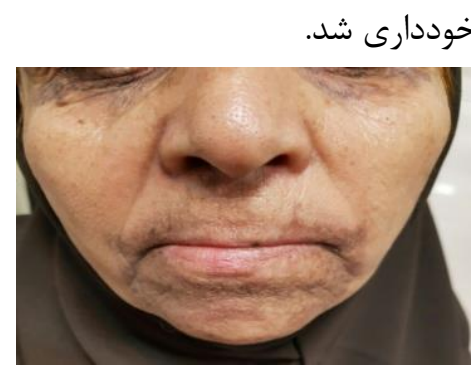

شكلا: بِيَمانتاسيون يرى اوربيت و يرى اورال،

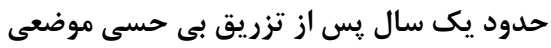

تسـت هــاى Skin Prick Test) SPT) و زيريوسـتى در تشخيص واكنش ازدياد حساسيت بـه طـور (Intradermal) كَسترده اي مورد استفاده قرار مى كيرند اما با توجه به احتمـال

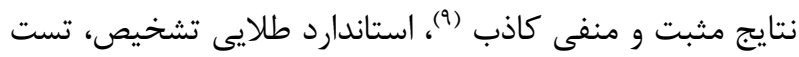
زيرجلدى (Subcutaneous) است كـهـ بايســ بـا رضـايت بيمـار انجام شده و در طى آن بيمار تحت نظارت باشد (•).

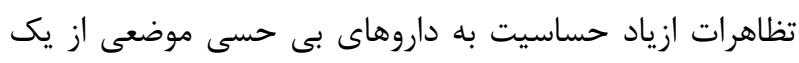

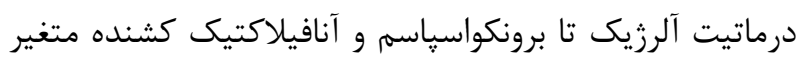
است (1)". اين مقاله يك مورد نادر از واكنش ازدياد حساسيت به محتواى كارتريج بى حسى موضعى راكزارش مى كند.

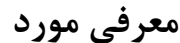

بيمار خانم اع ساله (قد بعاسانتىمتر و وزن ع ع كيلوگرم) در سال Vوץ| براى شكايت از دندانيزشك به علت نارضايتى از يريخمانتاسيون اطراف جشم و لب به سازمان نظام يزشكى مراجعه نمود. بيمار هيجَّنه سابقهى آلرزى به غذا و دارو و بيمارى سيستميك را كزارش نداد. سابقه خانوادكى آسم،

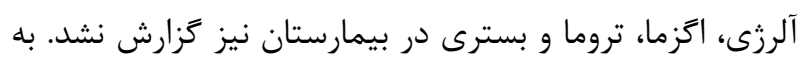
هنحام بررسى شكايت، بيمار بيان كرد كه حدود يك سال قبل، جهت كشيدن دندانهاى قدامى و يرمولر فك بالا به دندانيزشك مراجعه نموده بود. يّ از تزريق بى حسى موضعى، حدود يك ساعت بعد، ماكول و بيج هايى به رنخ سياه بهصورت حاد و در نواحى يرى اوربيت و يرى اورال ظاهر شد و در روز معاينه، اين ضايعات با حدود ناواضح در نواحى يرى اوربيت

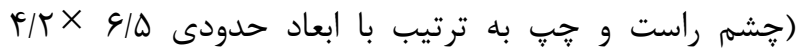

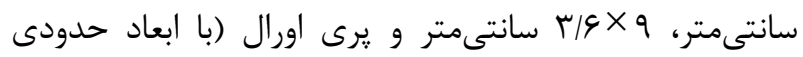

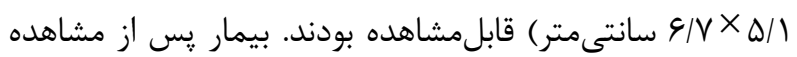

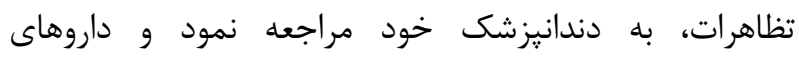
كورتيكواستروييد و ضدالتهاب (NSAID و يردنيزولون) براى وى تجويز شد كه در بهبود ضايعه بىاثر بودند. ضايعات در ابتدا يررنگ بوده و مشكلات زيبايى عديدهاى را براى بيمار ايجاد كرده بودند و به كفته بيمار يس از 4 ماه، ضايعات بامرور كمرنگتر شدند (شكل ()). طى يك سال كذشته، با مراجعات متعدد به متخصص يوست، داخلى و جراح فك و صورت، 
آنافيلاكتيك در اين مطالعه، احتمال واكنش آلرزيك را تا حدود

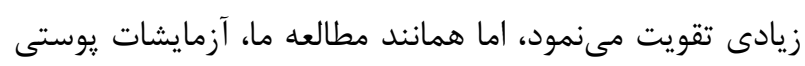

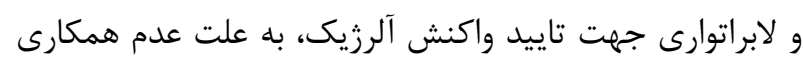
بيمار انجام نشد و تشخيص احتمالى صرفا از طريق علائم

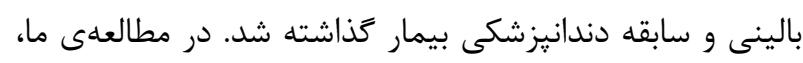

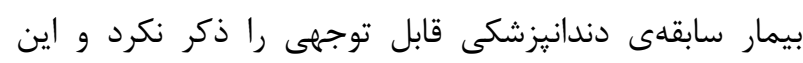

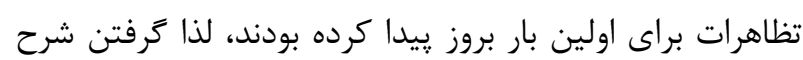

$$
\text { حال در تشخيص كمك كننده نبود. }
$$

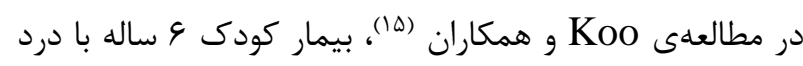

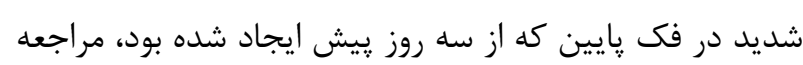

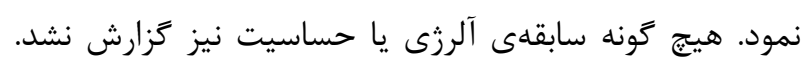

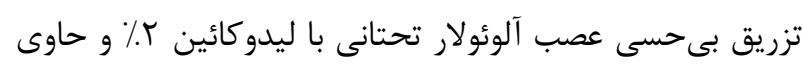

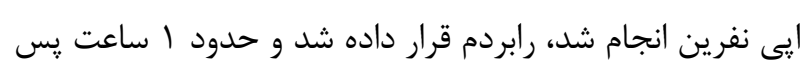

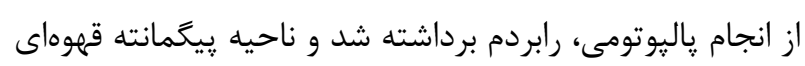

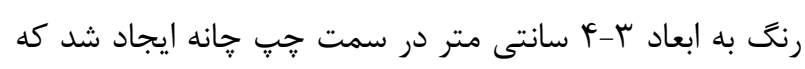

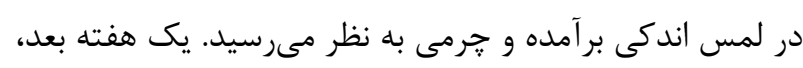

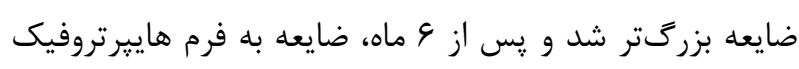

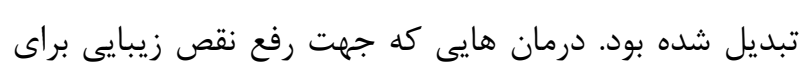

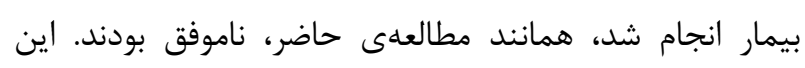

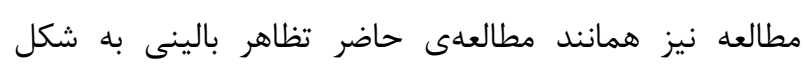

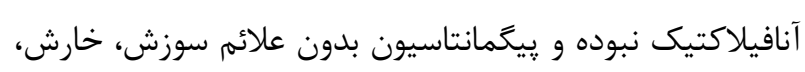

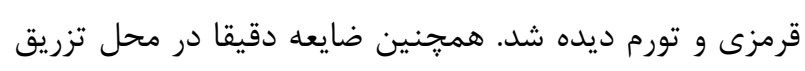

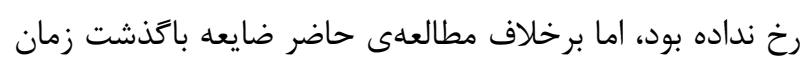

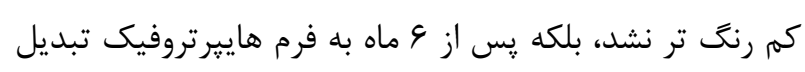
شد. در اين مطالعه نيز بيمار سابقهى قبلى واكنش ازياد

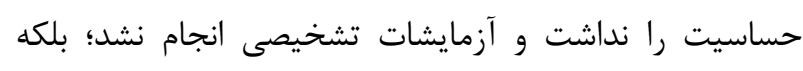
براساس شباهت بالينى ضايعه به "palpable purpura" در

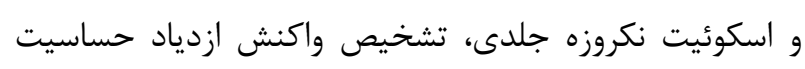
نوع براى بيماركذاشته شد.

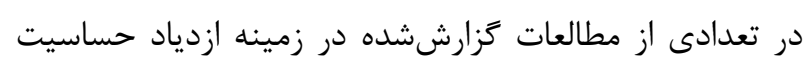

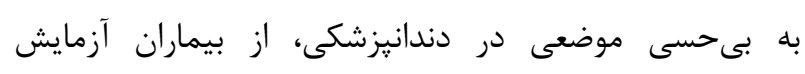

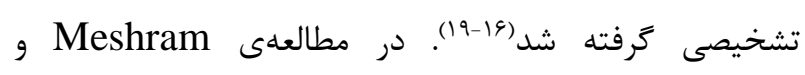

از بىحسى موضعى بلهور رايج در دندانيزشكى استفاده

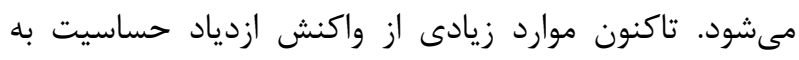
بى حسى موضعى در دندانيزشكى زَزارش شده است، اما تظاهر

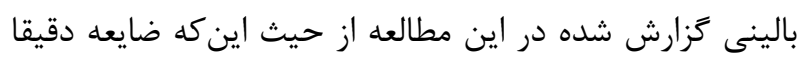
در محل تزريق نبوده و هيجزونه علائم التهاب (تورم، گرما،

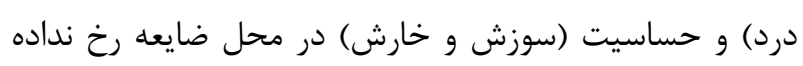
بود، منحصربهفرد مىباشد.

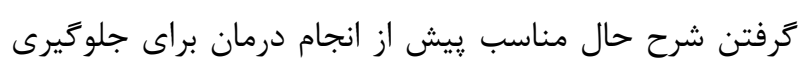

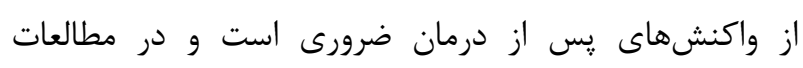

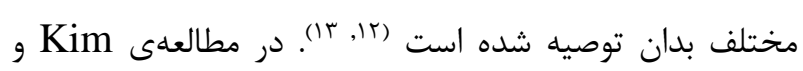

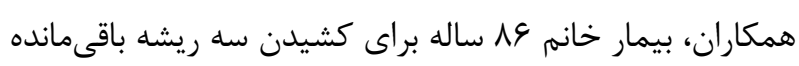

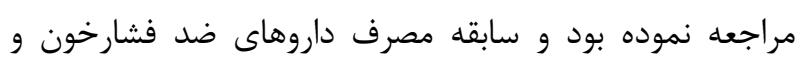

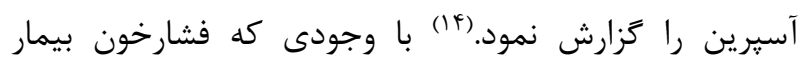
بهخوبى كنترل نشده بود، جراحى براى وى كنترالديكاسيون

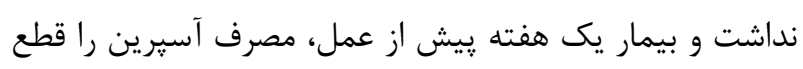

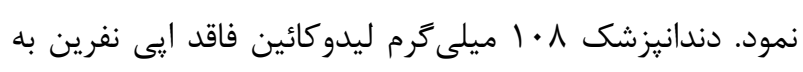
مخاط جينجيوال تزريق نمود. تمام علائم حياتى ازجمله

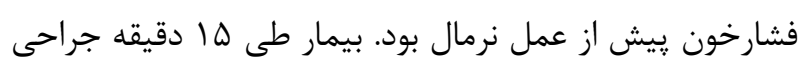

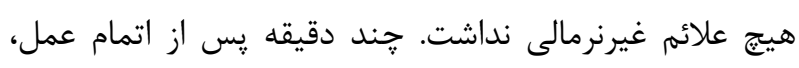

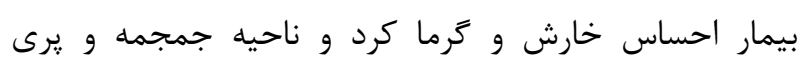

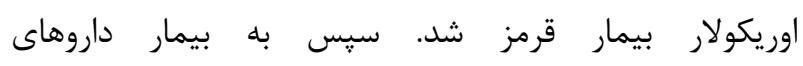
آنتىهيستامين تزريق شد و بيمار شروع به عرق كردن نمود و

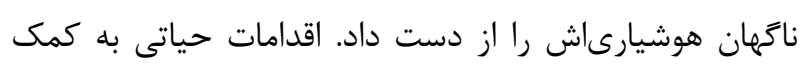

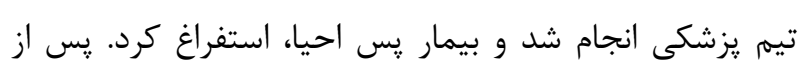

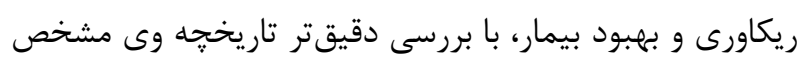

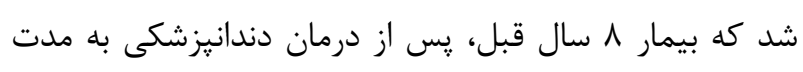

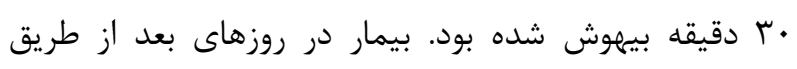

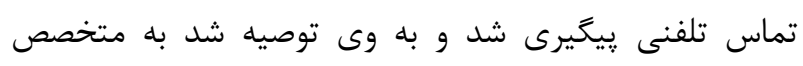
آلرزى مراجعه نمايد اما بيمار از انجام آن امتناع نمود. علائم كاهش هوشيارى و تهوع در اين بيمار را مىتوان به فشارخون

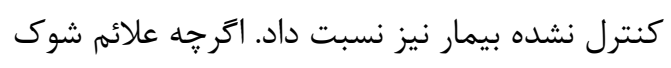


كَزارش شد. بيمار علائم تب، سردرد و تنكى نفس را كزارش نداد و با اجازهى والدين از كودى تست SPT كرفته شد و علت واكنش آلرزى به ليدوكائين شناخته شد. در مطالعهى

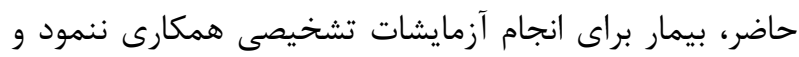
صرفا از نقص زيبايى ايجاد شده شكايت داشت. ازآنجاكه انجام آزمايشات تشخيصى ممكن است با احتمال پاتوزنز دائمى همراه

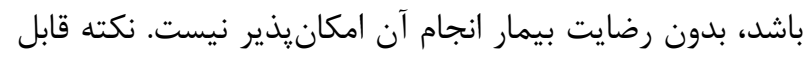
ذكر در اين مطالعه، توجه به وزن بيمار حين تجويز دوز آرامبخش موضعى و بى حسى موضعى تزريق شده بود. همجنين در كودكان در اولين مراجعه به دندانيزشكى، سابقه مرانه دندانيزشكى وجود ندارد و صرفا به سابقه يزشكى و خانوادگى درى

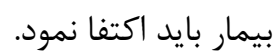
در تمامى مطالعات بيان شده، واكنش آنافيلاكتيك و علائم

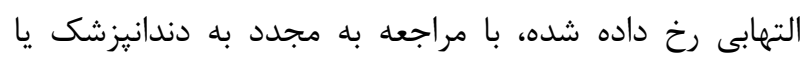

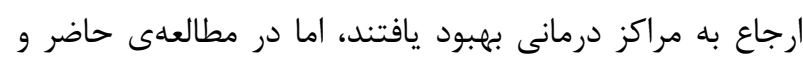

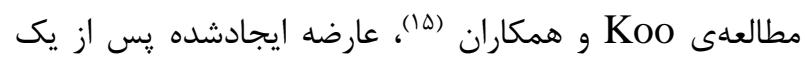
سال باقىمانده و به درمان مقاوم بودند. لذا تشخيص بالينى افتراقى در اين موارد از اهميت زيادى برخوردار است. تدابير و ملاحظات دندانيزشكى در صورت بروز علائم ازدياد حساسيت، بسيار حائز اهميت است. عوارض جانبى ازجمله واكنش هاى سايكوزنيك و توكسيك، بايد از واكنش هاى ازدياد حساسيت افتراق داده شوند. پِ از تشخيصهاى افتراقى ازدياد

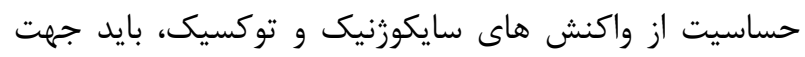
انجام آزمايشات حساسيت به ساير مواد بى حسى موضعى و ونى

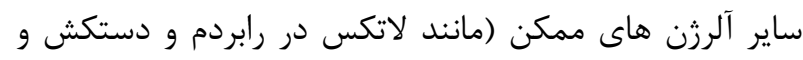

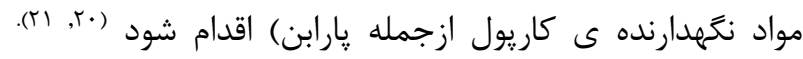
همجنين توصيه مىشود در هنعام استفاده از كاريول بىحسى

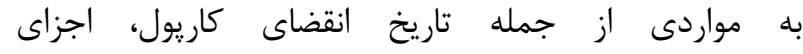
تشكيلدهندهى آن، تناسب غلظت مواد تشكيلدهنده و كشور سازنده آن دقت شود تا احتمال بروز واكنش هاى ازدياد

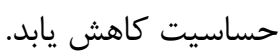

همكاران(V) ، بيمار آقاى •D ساله براى كشيدن دندان يوسيده فك پايين به دانشكده دندانيزشكى مراجعه نمود. از بيمار سابقهى بيمارى و آلرزى يرسيده شد و بيمار مورد خاصى را كزارش ننمود و طبق يروتكل دانشكده دندانيزشكى، تست

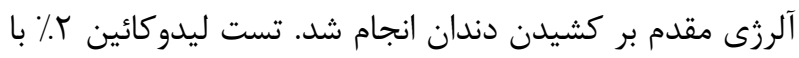

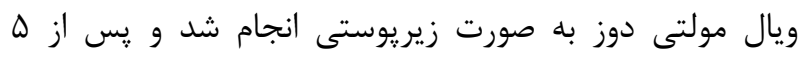
دقيقه علائم آلرزى به صورت اريتم در محل تزريق دورئ ديده شد.

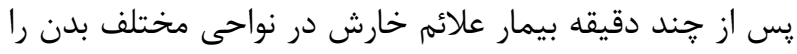
نشان داد و واكنش يوستى زنراليزه به صورت ضايعات برآمده سفت يا پايول هاى كوجكتر از 1 سانتى متر در كردن، تنه و اندام ها ديده شد. ضايعات با تزريق آنتىهيستامين و

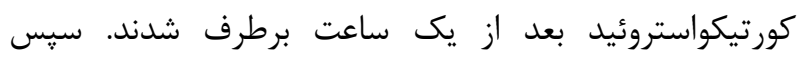
كشيدن دندان با بى حسى موضعى بويى واكائين (يس از ياسخ منفى بدن به تست) انجام شد.

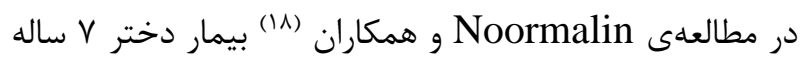

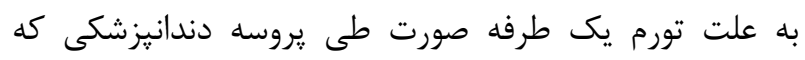
بلافاصله پس از زل ليدوكائين خوراكى و تزريق ليدوكائين ؟َ٪ حاوى إيى نفرين در ناحيه قدام فك بالا ايجاد شده بود، مراجعه

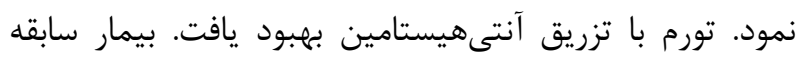

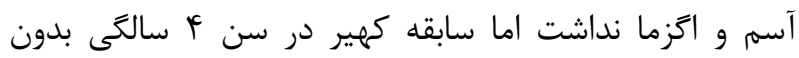
منشا خاصى را كزارش نمود و سابقه قوى خانوادىى كهير در خواهر و برادر و آنزيوادم در يدر گززارش شد. با توجه به احتمال

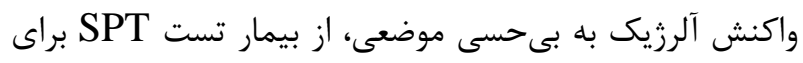

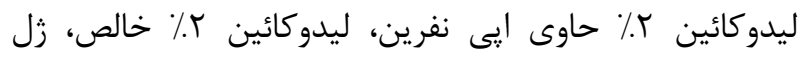

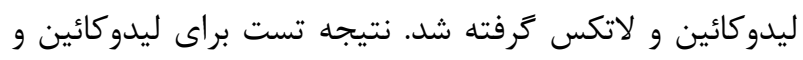

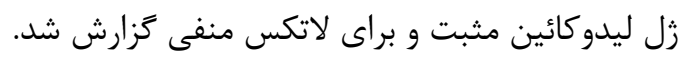

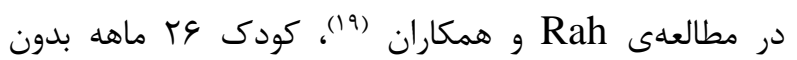
سابقه دندانيزشكى به علت يوسيدگى اكلوزال دو دندان مولراول شيرى فك پايين مراجعه نمود. با توجه به سن بيمار تصميم به درمان همراه با تجويز آرامبخش دهانى(يك ساعت قبل از لهين

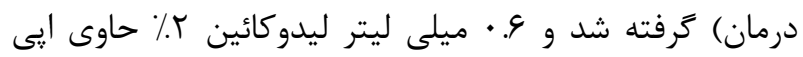

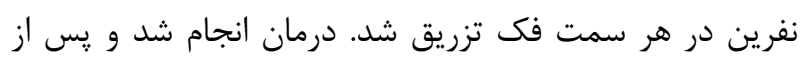
بازگشت به خانه، علائم تورم لب پايين و درد در محل تزريق 


\section{References:}

1.Speca SJ, Boynes SG, Cuddy MA. Allergic reactions to local anesthetic formulations. Dent Clin North Am. 2010 Oct;54(4):655-64. doi: 10.1016/j.cden.2010.06.006.

2.Malamed SF. Medical emergencies in the dental office. 6th ed. New York: Mosby Co; 2014.

3.Ball I. Allergic reactions to lignocaine. Br Dent J. $1999 \quad$ Mar;186(5):224-6. doi: 10.1038/sj.bdj.4800070.

4.Harper N, Dixon T, Dugue P, Edgar D, Fay A, Gooi $\mathrm{H}$, et al. Suspected anaphylactic reactions associated with anaesthesia. Anaesthesia. 2009 Feb;64(2):199. doi: 10.1111/j.13652044.2008.05733.x.

5.Cuesta-Herranz J, de las Heras M, Fernández M, Lluch M, Figueredo E, Umpierrez A, et al. Allergic reaction caused by local anesthetic agents belonging to the amide group. J Allergy Clin Immunol. 1997 Mar;99(3):427-8. doi: 10.1016/s0091-6749(97)70064-2.

6.Nakamura N, Tamagawa-Mineoka R, Masuda $\mathrm{K}$, Katoh N. Immediate-type allergic reactions to local anesthetics. Allergol Int. 2018 Jan;67(1):160-1. doi: 10.1016/j.alit.2017.07.003.

7.Fuzier R, Lapeyre-Mestre M, Mertes PM, Nicolas JF, Benoit Y, Didier A, et al. Immediate-and delayed-type allergic reactions to amide local anesthetics: clinical features and skin testing. Pharmacoepidemiol Drug Saf. 2009 Jul;18(7):595-601. doi: 10.1002/pds.1758.

8.Bhole M, Manson A, Seneviratne S, Misbah S. IgE-mediated allergy to local anaesthetics: separating fact from perception: a UK perspective. Br J Anaesth. 2012 Jun;108(6):90311. doi: $10.1093 / \mathrm{bja} / \mathrm{aes} 162$.

9.Thyssen JP, Menné T, Elberling J, Plaschke P, Johansen JD. Hypersensitivity to local anaesthetics-update and proposal of evaluation algorithm. Contact Dermatitis. 2008 Aug;59(2):69-78. doi: 10.1111/j.16000536.2008.01366.x.

10.Kvisselgaard A, Krøigaard M, Mosbech H, Garvey L .No cases of perioperative allergy to local anaesthetics in the Danish Anaesthesia Allergy Centre. Acta Anaesthesiol Scand. 2017 Feb;61(2):149-55. doi: 10.1111/aas.12833. Epub 2016 Nov 22.

11.Macy E. Local anesthetic adverse reaction evaluations: the role of the allergist. Ann Allergy Asthma Immunol. 2003 Oct;4(91):319-20. doi: 10.1016/S1081-1206(10)61674-2.

12.Mackley CL, Marks JG, Anderson BE. Delayed-type hypersensitivity to lidocaine. Arch Dermatol. 2003 Mar;139(3):343-6. doi: 10.1001/archderm.139.3.343.
13.Finder RL, Moore PA. Adverse drug reactions to local anesthesia. Dent Clin North Am. 2002 Oct;46(4):747-57. doi: 10.1016/s00118532(02)00018-6.

14.Kim H, Lee J-M, Seo K-S, Kwon SM, Row HS. Anaphylactic reaction after local lidocaine infiltration for retraction of retained teeth. J Dent Anesth Pain Med. 2019 Jun;19(3):175-80. doi: 10.17245/jdapm.2019.19.3.175.

15.Koo Y-H, Dym H. An unusual complication with local anesthetic injection. Columbia Dental Review. 2000;(5): 30-32.

16.Lee J, Lee J-Y, Kim HJ, Seo K-S. Dental anesthesia for patients with allergic reactions to lidocaine: two case reports. $J$ Dent Anesth Pain Med. 2016 Sep;16(3):209-12. doi: 10.17245/jdapm.2016.16.3.209.

17.Meshram VS, Meshram PV, Lambade PN, Tiwari MS. An Unusual Complication with Use of Lignocaine: A Case Report. J Clin Diagn Res. 2015 Jun;9(6):ZD14-5. doi: 10.7860/JCDR/2015/12757.6064.

18.Noormalin A, Shahnaz M, Rosmilah M, Mujahid S, Gendeh B. IgE-mediated hypersensitivity reaction to lignocaine- a case report. Trop Biomed. 2005 Dec;22(2):179-83.

19.Rah Y, Lee J, Ra J. Hypersensitivity to Local Anesthetics: A Case Report. J Korean Acad Pediatr Dent. 2017 Aug;44(3): 365-369.

20.Grzanka A, Wasilewska I, Śliwczyńska M, Misiołek H. Hypersensitivity lo local anesthetics. Anaesthesiol Intensive Ther. 2016;48(2):128-34. doi: 10.5603/AIT.a2016.0017.

21.Shojaei AR, Haas DA. Local anesthetic cartridges and latex allergy: a literature review. $J$ Can Dent Assoc. 2002 Nov;68(10):622-5. 